\title{
Market dynamics as a driver towards the evolution of research needs: the case of up-flow anaerobic sludge blanket seeding granules
}

\author{
Ndeke Musee ${ }^{1,2 *}$ and Leon Lorenzen ${ }^{1,3}$ \\ ${ }^{1}$ Department of Process Engineering, Stellenbosch University, Private Bag X, Matieland 7602, South Africa \\ ${ }^{2}$ Natural Resources and the Environment, CSIR, PO Box 395, Pretoria 0001, South Africa \\ ${ }^{3}$ Snowden Mining Industry Consultants, 87 Colin Street, West Perth, WA 6005, Australia
}

\begin{abstract}
Market dynamics offer positive (incentive) or negative (disincentive) feedback loops that shape the research needs for, or certain aspects of, a particular technology. Our case study results illustrate how market dynamics have influenced the evolution of research needs in the wastewater treatment sector, with specific emphasis on research on the seeding granules used to start up-flow anaerobic sludge blanket (UASB) reactors. Because of insufficient data on the actual market demand for seeding granules for UASB plants, surrogate data, on the number of UASB plants installed internationally from 1970 to 2007, were used to predict the potential future demand for seeding granules. Secondly, we also determined whether or not such a demand would provide sufficient economic justification for the installation of one or more plants for manufacturing seeding granules in South Africa. The direct relationship between the demand for seeding granules and increased numbers of UASB plants was based on the premise that the start-up of each plant required a seeding inoculum before effluent could be treated. Three methods were used to obtain the data used in this study, namely: a literature survey, a questionnaire survey, and interviews with people having expert knowledge of wastewater treatment technologies. Our findings suggest that the UASB technology has largely been marginalised in the wastewater treatment market because of the introduction of competing technologies, and due to high initial capital costs. As a result, South African market demand for the seeding granules is likely to be very small or non-existent, because the number of new UASB plants installed per year is likely to decrease in future. Secondly, our research suggests that market dynamics, political contexts and technologies will continue to change, exerting an increasing downward influence on the UASB technology over time.
\end{abstract}

Keywords: market dynamics, UASB, EGSB, seeding granules, market demand, inoculum

\section{Introduction}

\section{Historical context of UASB technology development}

The up-flow anaerobic sludge blanket (UASB) technology was developed in the late 1960s by Bill Ross in South Africa (Ross, 1989). This was followed in the early 1970 s by the work of Lettinga and co-workers (Lettinga et al., 1979), who solved the problem of how to ensure a long residence time of the seeding inoculum in a UASB reactor. Thereafter, the UASB process became among the most efficient treatment technologies for high strength effluents, and a stable anaerobic wastewater treatment technique.

Several reasons contributed to the relative success of the UASB technology up to the 1990 s, when compared to other forms of effluent treatment technologies that were introduced during the same period. The most salient reasons include the following: First, the basic knowledge about anaerobic digestion (AD) and particularly the UASB reactor was freely accessible to companies that were interested in producing parts of the reactor. This cooperation between industry and research institutions led to several new firms entering the market. Unlike many other technological discoveries where the intellectual property was

\footnotetext{
* To whom all correspondence should be addressed.

용 +27 12841 4134; fax: +27 21842 7738;

e-mail: nmusee@csir.co.za; museen2012@gmail.com

Received 4 October 2011; accepted in revised form 19 November 2012.
}

protected through a variety of patent and licensing instruments - the UASB technology was never patented (Foresti, 2001). Both the Biothane Corporation and Paques Inc., the world leaders in this technology, only patented partial improvements to the reactor. Since then, the UASB reactor design has continued to be refined (Nederhorst et al., 1986) to cater for effluents derived from a variety of different industrial processes.

Secondly, political factors propelled the development and wide application of the UASB technology in Europe and North America. The underlying reason for this was the energy crisis of the early 1970s, which caused severe fuel shortages in Europe and North America, and particularly in the USA, which was heavily dependent on oil supplies from the Middle East (McBNeill, 2000). While the oil shortage only lasted for a few months, and supplies were 'back to normal' by March 1974, the price of crude oil had quadrupled during the crisis period. In Europe, the Netherlands was the country most adversely affected by the oil crisis and both the Netherlands Government and industry invested heavily in finding alternative energy sources. In this context, the UASB technology proved to be very effective at treating high strength effluent and also produced 'free' energy in form of biogas (Raven and Verbong, 2004).

On the other hand, the increased international attention directed towards waste minimisation and recycling that started in the 1960s forced companies to seek technology alternatives that could treat industrial effluents to acceptable standards before their release into the environment. In addition, governments started to exert increasing pressure on companies to meet their environmental-related obligations by enacting stringent 
control legislation coupled with punitive penalties against companies that were responsible for pollution (McNeill, 2000; Raven and Verbong, 2004). These mechanisms helped to motivate companies to adopt new environmental technologies (e.g. UASB, anaerobic filter, etc.) to treat industrial waste streams to acceptable standards before discharge. In this period the UASB technology gradually gained wider market acceptance in diverse industries, particularly in Europe (Raven and Verbong, 2004).

Finally, rapidly growing public environmental awareness during the 1960s and 1970s forced many governments to introduce new and increasingly stringent legislation to protect surface and ground waters from pollution and created incentives for industries to explore new methods of wastewater treatment and disposal (McNeill, 2000). This again propelled the growth in the number of pilot plants, advanced basic knowledge about anaerobic digestion and purification, and resulted in UASB reactors becoming increasingly widely used in diverse industries such as: fermentation (brewing), sugar refining, potato processing, soft drink production and food canning. A detailed account of the underlying reasons for the success of UASB technology has been provided by Raven and Verbong (2004).

\section{Rationale and aims of the study}

In South Africa, the Government has funded research, supported by the Water Research Commission (WRC), on the development and cultivation of UASB seeding granules for slightly more than a decade. The granules comprise of engineered anaerobic consortia that expand the catabolic diversity of sludge, shorten the period of adaptation to recalcitrant and toxic substrates, and possess the capability to degrade complex organic waste streams (Liu et al., 2003). The cultivation of granules in South Africa was mainly to ensure constant access to a guaranteed high-quality supply of granular sludge for existing UASB-type reactors, in the event that a reactor became 'poisoned' through the acidification process or through the action of foreign chemical contaminants in the effluent, and, secondly, to meet the growing need for high-quality granular sludge in the South African market, for treating high-strength wastewaters in the newly established UASB reactors (Britz et al., 1999, 2002).

The challenges that face developing countries in accessing high-quality granular sludge have been well expressed by Britz and co-workers (Britz et al., 1999, 2002). In South Africa, this challenge was addressed through the development of specialised microbial consortia by the induction of a desirable biochemical pathway (Britz et al., 1999; Britz and Van Schalkwyk, 2002) as well as by designing and fabricating a reactor at laboratory scale to produce granules (Els et al., 2005). The scaling-up findings of Els and co-workers suggested that mass culturing of granules held great promise for application in the UASB technology, specifically in developing countries like South Africa.

However, the findings of these studies and the small size of the laboratory-scale reactors revealed how difficult it was to conclusively establish full-scale operating parameters and conditions for a commercial-scale reactor for fabricating seeding granules. Therefore, to realise the goals, objectives and outcomes of the project, there was a clear need to design, fabricate, seed, and optimise a pilot-plant for producing UASB granules ranging from $100-1000 \mathrm{~kg} /$ day before designing and developing a full-scale plant. This approach made it essential to undertake additional research to establish, firstly, the optimal operating parameters, and secondly, the environmental conditions suitable for fabricating granular sludge in a full-scale industrial plant. Therefore, before the necessary funding could be established to undertake this approach, the Water Research Commission (WRC) commissioned a desk-top study (Musee and Lorenzen, 2009) to establish the size of the market for granules in UASB applications - both nationally and internationally - as a basis to gauge the viability of a commercial plant.

To date, there has been limited and disjointed market research internationally on the extent of the demand for UASB seeding granules in the wastewater treatment sector. Therefore, in this study, our primary objective was to establish the market trends in the demand for the granular sludge in South Africa and internationally, and, secondly, to demonstrate how the market dynamics in previous years have directly or indirectly influenced the evolution of research needs in this field.

Therefore, the specific objectives of this study were to:

- Establish the suppliers of UASB granules for wastewater treatment in South Africa for industrial and municipal treatment plants

- Establish the producers and suppliers of UASB granules internationally

- Establish the market size of UASB granules both in South Africa and internationally through market trend analysis

- Investigate whether or not the introduction of new technologies into the wastewater treatment market may have introduced a 'phase out effect' on the UASB technology

- Because of the lack of published data on the international demand for seeding granules used in the UASB, data on the growth in the market for the UASB technology since its inception in the 1970s was used as a surrogate to represent the demand for the seeding granules.

\section{Anaerobic digestion systems: The historical perspective}

To fully appreciate the impact of market dynamics as a driver of research needs for a given process or product, it is essential to understand the historical perspective; a brief overview of the salient aspects in the context of AD systems are summarised below.

For over a century, anaerobic processes have been applied to treat effluents from industrial and domestic sources (McCarty, 1981) and success of the anaerobic treatment processes has been most remarkable over the past 3 decades (Frankin, 2001). By 2001, 25 years after the construction of the first commercial high-rate anaerobic treatment plant for industrial wastewater in the sugar industry (a UASB plant), the technology had been extended to a wide variety of industries in over 65 countries, and about 1400 plants had been built globally (Frankin, 2001). These plants accounted for approximately $65 \%$ of the total number of anaerobic treatment installations for treating industrial effluents.

The success of the anaerobic treatment systems has been attributed to benefits such as the apparently low operating costs, compact construction, generation of energy through biogas production, low surplus sludge production, as well as the production of re-usable water and fertiliser - all of which provide favourable economics (Environasia, 2001; Aiyuk et al., 2006). However, for $\mathrm{AD}$ processes to be acceptable in the wastewater treatment industry, especially in developing and semi-developed countries like South Africa, the systems should have a minimal need for highly skilled manpower, low operating and maintenance costs, low energy inputs, high system throughput and small 'footprint size' in terms of land requirements for constructing the plant. In addition, the units should be simple, reliable and of low cost. Generally, the AD technology's high 
potential for wastewater treatment in developing countries has been proven for both domestic and industrial purposes, and the technology is considered to be technically and economically feasible (Foresti, 2001).

However, while the anaerobic technology for wastewater treatment has several distinct advantages, it also has a number of limiting features (Lettinga et al., 1999). The demerits include the high sensitivity of methanogenic bacteria in $\mathrm{AD}$ systems to a large number of chemical compounds. This limits the types of effluents that can be treated using AD technologies, although, in certain cases, the anaerobic organisms have the ability to adapt to some chemical compounds. Secondly, the first start-up of an installation lacking proper seeding sludge is time-consuming, because of the low growth yield of anaerobic bacteria, which sometimes may take up to 12 months to develop. This leads to long retention times before the treated waste can be stabilised, which in turn increases operational costs.

Finally, the anaerobic treatment of wastewater containing sulphur compounds is usually accompanied by the generation of unpleasant odours due to the production of hydrogen sulphide. An effective solution to this problem requires the incorporation of a micro-aerophilic post-treatment step to convert any sulphide present to elemental sulphur. Despite these shortcomings, the performance of the anaerobic reactions can be optimised by improved reactor design and careful control of feed rate (Harada et al., 1994; Allen and Liu, 1998).

\section{Anaerobic digestion systems: The technological perspective}

The wide variety of wastewaters that are generated (in terms of characteristics, volume, composition, frequency, etc.) from over 30 different types of industries (pulp and paper, beverages, breweries, chemicals, pharmaceuticals, etc.) triggered the development of an array of different anaerobic technologies because the 'one technology solution fits all' approach was technically untenable. Presently the anaerobic technologies are used to treat a wide variety of effluents at different scales.

The anaerobic systems are broadly classified as: low-rate - e.g. anaerobic lagoon (Tchobanoglous and Burton, 1991; Allen and Liu, 1998); continuously stirred tank reactor - e.g. CSTR (de Mes et al., 2003); high-rate - e.g. UASB (Lettinga et al., 1979; Lettinga et al., 1980; Lettinga, 1995; Verstraete et al., 1996; Seghezzo et al., 1998; Aiyuk et al., 2006); anaerobic filter (AF) (Lettinga et al., 1979; Speece, 1983; Lim and Lee, 1991; Jördening and Buchlonz, 1999); fluidised-bed (FB) system (Jördening and Buchlonz, 1999; IEA Bioenergy, 2001; van Lier, 2008); hybrid (H) systems (Elmitwalli, 2000; Paques ADI, 2001); ultra-high rate - e.g. expanded granular sludge bed (EGSB); or internal circulation (IC) reactor anaerobic processes (Versprille et al., 1994; Zoutberg and de Been, 1997; Gavrilescu, 2002).

In the last few years, the EGSB has become the biggest competitor to the UASB technology, mainly because of its distinctive merits such as flexibility, simplicity, ability to accept high influent liquid and gas velocities, high circulation ratios that create inherent hydraulic balancing capacity, and high volumetric loading rates ranging from 15 to $30 \mathrm{~kg} \mathrm{COD} / \mathrm{m}^{3}$ (Gavrilescu, 2002). In addition, the EGSB technology is suitable for regions where land is at a premium (Habets, 1999). For example, the internal circulation process known as BiopaqIC (Pereboom and Vereijken, 1994), promoted by Paques, is a popular ultra-high rate anaerobic reactor (Allen and Liu, 1998; Habbets, 1999), and is widely used in the pulp and paper industry, in preference to the standard UASB. The market trends are discussed under 'Results and discussion'. From a market dynamics viewpoint, the global growth in the use of UASB plants can be predicted by comparing UASB with the use of competing technologies such as ADI systems and EGSB.

\section{Materials and methods}

Three methods were used in this study to establish the extent and characteristics of the market dynamics for UASB technology in South Africa and internationally. These were: a literature survey, technical questionnaires, and telephonic interviews. The results obtained from the different approaches provided complementary information that was used to cross-validate the integrity and completeness of the data and information derived by each method. The following sections summarise each of the approaches used to solicit data.

\section{Questionnaires}

Two types of questionnaires were used to assess the market dynamics of the seeding granules used in UASB plants. The first questionnaire (referred to hereafter as the Type-I questionnaire) was designed to solicit information from current industrial users of UASB technology for effluent treatment in South Africa. The second questionnaire (referred to hereafter as the Type-II questionnaire) was designed to solicit data and information from experts in the AD systems, with a particular focus on UASB technology market trends in South Africa and globally. Both questionnaires were sent out to each of the target recipients and were followed up with telephone interviews.

The companies and AD experts listed on the database for the exercise were identified through internet-based sources (websites), literature reviews, and personal contacts.

The decision to design and develop 2 types of questionnaires was aimed at accessing the best possible data, knowledge and insights that we felt were essential requirements for deriving informed conclusions and recommendations on the economic feasibility of the commercial production of UASB granules in South Africa. The two-questionnaire approach was designed to minimise the possibility of collecting inadequate data through over-reliance on a single source (industries or experts). Another motive was the need to take into account the different perspectives arising from the study objectives, which could not easily be achieved by soliciting data and information from a single source (experts or industries) or with a single method (interviews or questionnaires).

The Type-I questionnaire was sent to 13 treatment plants in different industrial and public sectors such as: breweries, food and beverages, municipal wastewater treatment plants, chemical and petrochemical, etc., which we presumed to be using UASB effluent treatment technology according to information supplied by experts knowledgeable in the wastewater treatment industry in South Africa. The primary aim of the questionnaire was to capture data and information on aspects such as: (i) the suppliers of UASB seeding granules to the plant; (ii) the operational base of the suppliers - whether this was based in South Africa or overseas; (iii) the cost of granules per unit tonnage (US dollars per tonnage); (iv) recent trends in the quantities of effluent treated using UASB over a certain period of time; (v) the performance of the granules (efficiency percentage) as well other alternative technologies considered or installed in the plants in place of UASB technology; (vi) information concerning the ready availability of seeding granules in South Africa; and 
(vii) the type of industrial processes for which the effluent produced was treated using the UASB technology.

On the other hand, the Type-II questionnaire was designed to facilitate structured interviews with experts in the AD systems (particularly UASB technology applications) in South Africa. Eighteen experts were identified based on a database that was compiled through telephone calls and interviews with a core group of experts in the wastewater treatment industry who were known to the authors. Each expert was mailed a questionnaire, and a follow-up telephone call was made to arrange for an interview. The experts were distributed among different economic sectors, namely: academic, consultancy, government departments, and research and development.

\section{Literature review}

The first part of the project aimed to establish the existence of reported findings on the market dynamics of the UASB technology since its inception from the 1970s, though only limited information was found in the literature. The results on the market dynamics of anaerobic treatment systems derived from the literature review are summarised under 'Results and discussion' below. Therefore, to broaden the scope of our literature survey, we contacted the South African representatives of the major international suppliers of UASB technology to provide additional information, and new perspectives.

\section{Interviews}

Structured interviews with experts were used to gain knowledge and clear understanding of the workings and the current status of the UASB technology as well as general information on the companies that operated UASB technology systems in South Africa, and globally. Prior to the interviews, a set of questions (Type-II questionnaire) were provided to the experts to help them to prepare for the interview.

\section{Results and discussion}

We found that the data and information on the growth of UASB plants globally since the 1970 s were scanty and often inconsistent. This was primarily due to the proprietary nature of the data and information held by the technology vendors, and made it impossible to verify the overall accuracy and completeness of the data and information published in the literature. Statistics for the same year on the number of EGSB or UASB plant installations differed considerably, even when sourced from the same technology vendor. This appeared to be dependent on the source of the data, in particular, whether the information was derived from vendor-supplied statistics appearing on the company website, or consisted of data sourced from peer-reviewed technical articles. Also, we noted that data on the number of installations per year from the same vendor differed substantially when the website was re-visited after a period of several months. Finally, worldwide data and information related to many aspects of waste management are limited and incomplete; the statistics reported in this study on AD systems, and specifically for UASB, have similar deficiencies.

Our conclusions on the market growth demand for seeding granules are based on the hypothesis that the increasing application of seeding granular sludge is directly proportional to the increase in the number of UASB plants installed locally (South Africa) and internationally. However, while granular sludge may cease activity in certain UASB plants during the effluent treatment process, which may necessitate re-seeding, the experts that we consulted considered that such demand was insignificant because international experience has shown that such cases only occur 2 or, perhaps, 3 times in every 10 years. In addition, a UASB plant operating optimally produces excessive seeding granules, and consequently does not require externally-sourced seeding granules.

Our results are presented in 3 formats, in order to help derive conclusions on the influence of market dynamics on the demand for UASB granules. The perspectives were expressed in terms of the literature survey results, scenario-derived results (e.g. AD plants distribution globally, vendor-based AD systems market analysis, etc.), and the results of the questionnaire survey. The systematic presentation of the available data helped us to establish how the market dynamics impacted on the demand for UASB granules in South Africa, and internationally.

\section{Results of the literature review}

In this section, a brief historical overview of the growth in numbers of UASB plants internationally is presented as the basis for establishing the size of the current demand for granular sludge in South Africa and globally. The findings are essential as they offer insights into the dynamics of the granular sludge market over a specified period of time. Equally important, whilst the data on the global annual growth in the numbers of UASB plants were scarce, erratic, and, to some extent inconsistent, our findings provide useful insights into the market dynamics of the seeding granules. In this context, the global statistics on UASB plants reported in peer-reviewed journals and reports up to 2000 (Nederhorst et al., 1986; Pauss and Nyns, 1990; Lettinga and Hulshoff Pol, 1991; Fang et al., 1994 ; Ross, 1994; Alves et al., 2000; Raven and Verbong, 2004) are summarised to provide preliminary growth trends on the demand for seeding granules. However, these published findings do not provide a comparative perspective of UASB versus other AD effluent treatment technologies.

In 1985, a committee of experts from industry, research institutes and government concluded that anaerobic treatment was a valuable technology for industrial wastewater that contained easily decomposable organic material (Raven and Verbong, 2004). By that time, about 30 anaerobic reactors had been built in several countries. With the exception of one fluidised-bed system at Gist Brocades, the plants were all UASB reactors, and their distribution by industry source and country is shown in Table 1. Notably, of the total of 51 UASB plants operated worldwide by 1984, 27 were in The Netherlands (about $53 \%$ ) but none in Africa or Australasia.

Through a broad grouping of the industries using the UASB technology by 1984, the market distribution of the plants can be summarised as follows. Food-based industries comprised $59 \%$ of the market share, while brewery and alcohol-producing industries had $31 \%$ of the market share, and the remaining $10 \%$ were mostly represented by the paper and meat-processing industries.

Lettinga and Hulshoff Pol (1991) presented statistics on the UASB plants that had been built before September 1990. A total of 205 plants, with an estimated effluent treatment capacity of $339600 \mathrm{~m}^{3}$, were reported (see Table 2). One of the key limitations of these statistics was the absence of information on distribution of UASB plants by country, or continent. The plant classification system was based on the wastewater industrial source, for instance, alcohol, brewery, pulp and paper, or foodrelated industries. The figures of Lettinga and Hulshoff Pol 


\begin{tabular}{|l|l|c|}
\hline \multicolumn{3}{|c|}{$\begin{array}{c}\text { Table 1 } \\
\text { Distribution of UASB plants worldwide by 1984 } \\
\text { (from Nederhorst et al., 1986) }\end{array}$} \\
\hline \multirow{2}{*}{ Industry Source } & Country & $\begin{array}{c}\text { Number of } \\
\text { plants }\end{array}$ \\
\hline Beet sugar & Netherlands & 7 \\
\cline { 2 - 3 } & Germany & 2 \\
\cline { 2 - 3 } & Austria w & 1 \\
\hline Liquid sugar & Netherlands & 1 \\
\hline Potato processing & Netherlands & 8 \\
\cline { 2 - 3 } & USA & 1 \\
\cline { 2 - 3 } & Switzerland & 1 \\
\hline Potato starch & Netherlands & 2 \\
\cline { 2 - 3 } & USA & 1 \\
\hline Corn starch & Netherlands & 1 \\
\hline Wheat starch & Netherlands & 1 \\
\cline { 2 - 3 } & Ireland & 1 \\
\cline { 2 - 3 } & Austria & 1 \\
\hline \multirow{5}{*}{ Alcohol } & Netherlands & 1 \\
\cline { 2 - 3 } & Germany & 1 \\
\hline Yeast & USA & 1 \\
\hline Brewery & Netherlands & 1 \\
\cline { 2 - 3 } & USA & 1 \\
\hline Crustaceans & Netherlands & 1 \\
\hline Abattoir & Netherlands & 1 \\
\hline Dairy products & Canada & 1 \\
\hline Paper & Netherlands & 2 \\
\hline Preserved food & Netherlands & 1 \\
\hline Alcohol production & Thailand & 12 \\
\hline Total & & \\
\hline
\end{tabular}

(1991) were corroborated by Grotenhuis (1992), who indicated that the UASB technology had rapidly grown in popularity worldwide, with over 200 full-scale installations by 1992

Fang and co-workers (Fang et al., 1994) reported that by 1994 there were over 300 UASB plants in operation worldwide that were treating high-strength effluents - mostly from brewery, potato, starch and sugar-processing industries. However, these statistics were of limited use because they lacked data on the distribution of UASB plants with respect to industrial sectors or the country of operation. Nevertheless, the data show rapid growth of UASB plants over a short period of time, because the numbers increased from 51 in 1984 (Raven and Verbong, 2004) to 201 in 1990 (Lettinga and Hulshoff Pol, 1991), and to over 300 (Fang et al., 1994) by 1994. Indirectly, this suggested that the market for granular sludge grew by $490 \%$ within the 10-year period from 1984 to 1994.

Alves et al. (2000) indicated that UASB reactors represented more than $65 \%$ of all the AD systems installed for treating industrial wastewater worldwide. Numerically, this represented more than 900 UASB units operating worldwide. However, the authors did not provide useful breakdown of the data in terms of the country of operation or industry sector served. The statistics for the period between 1994 ( $>300$ plants) and 2000 (>900 plants) suggest a growth rate exceeding $200 \%$ in 6 years for application of UASB technology to treat wastewater.

Although the studies of Fang et al. (1994) and Alves et al. (2000) lacked information on the distribution of plants with respect to country of operation or industry sector served, the data provided insights into regions with high potential market

\begin{tabular}{|l|c|c|}
\hline \multicolumn{3}{|c|}{$\begin{array}{c}\text { Table 1 } \\
\text { Full-scale UASB installations worldwide before } \\
\text { Septer 1990 (from Lettinga }\end{array}$} \\
\hline Wastewater & Number & $\begin{array}{c}\text { UASB-volume } \\
\text { ( }^{3} \text { ) }\end{array}$ \\
\hline Alcohol & 20 & 52000 \\
\hline Baker's yeast & 5 & 900 \\
\hline Bakery & 2 & 347 \\
\hline Brewery & 30 & 60600 \\
\hline Candy & 2 & 350 \\
\hline Canneries & 3 & 2800 \\
\hline Chemical & 2 & 2600 \\
\hline Chocolate & 1 & 285 \\
\hline Citric acid & 2 & 6700 \\
\hline Coffee & 2 & 1300 \\
\hline Dairy and cheese & 6 & 2300 \\
\hline Distillery & 8 & 24000 \\
\hline Domestic sewage & 3 & 3200 \\
\hline Fermentation & 1 & 750 \\
\hline Fruit juice & 3 & 4600 \\
\hline Fructose production & 1 & 240 \\
\hline Landfill leachate & 6 & 2495 \\
\hline Paper and pulp & 28 & 67197 \\
\hline Pharmaceutical & 2 & 400 \\
\hline Potato processing & 27 & 25610 \\
\hline Rubber & 1 & 650 \\
\hline Sewage sludge liquor & 1 & 1000 \\
\hline Slaughterhouse & 3 & 950 \\
\hline Soft drinks & 16 & 1385 \\
\hline Starch (barley, corn, potato, wheat) & 3 & 23500 \\
\hline Sugar processing & 4 & 8500 \\
\hline Vegetable and fruit & & 339609 \\
\hline Yeast & \\
\hline Totals & 205 & \\
\hline
\end{tabular}

demand. More specifically, the statistics from these studies were important to our study because they indicated the rapid growth rate of the UASB technology worldwide, as the number of UASB plants increased from less than 5 in the 1970 s to approximately 1000 plants by 2000 . This suggested a wide acceptance of the UASB technology in the wastewater treatment industry. The growth is phenomenal given that many other types of effluent treatment technologies have disappeared from the market after the first 5 years since their introduction, as discussed elsewhere in this paper. Conversely, the UASB technology exhibited dramatic and sustained market growth from the mid-1980s to 2000. Secondly, the statistics also show, indirectly, that within this period the demand for the seeding granular sludge was high internationally because many new UASB plants were installed each year.

According to Pauss and Nyns Report (Pauss and Nyns, 1990), there were 3 main suppliers of the UASB technology worldwide during the 1980s, namely, the Paques BV (The Netherlands), Biotim (Belgium), and SGN (France). Moreover, by October 1991, 106 full-scale Paques BV UASB plants were in operation worldwide, ; their distribution per country is summarised in Table 3. Ross (1994) analysed the types of anaerobic digestion plants in use worldwide. The findings showed that 80 full-scale anaerobic plants were constructed by Biotim of Germany and SGN of France, mainly comprising of different types of digesters (e.g. UASB, anaerobic contact, up-flow 


\begin{tabular}{|c|c|c|c|}
\hline \multicolumn{4}{|c|}{$\begin{array}{c}\text { Table } 3 \\
\text { Distribution of UASB plants commissioned by } \\
\text { Paques BV (The Netherlands) for industrial effluent } \\
\text { treatment (1981-1991) (from Ross, 1994) }\end{array}$} \\
\hline Country & $\begin{array}{l}\text { Total UASB } \\
\text { vol. }\left(\mathbf{m}^{3}\right)\end{array}$ & \begin{tabular}{|c|} 
Total COD \\
load $\left(\mathbf{k g} \cdot \mathbf{d}^{-1}\right)$
\end{tabular} & $\begin{array}{l}\text { Number } \\
\text { of plants }\end{array}$ \\
\hline Australia & 2635 & 36500 & 4 \\
\hline Austria & 2300 & 3000 & 2 \\
\hline Brazil & 31615 & 294585 & 27 \\
\hline Canada & 10000 & 186000 & 2 \\
\hline Finland & 1520 & 39500 & 1 \\
\hline France & 3194 & 30050 & 4 \\
\hline Germany & 4122 & 34714 & 5 \\
\hline India & 22500 & 225000 & 5 \\
\hline Ireland & 2200 & 17000 & 1 \\
\hline Israel & 750 & 7200 & 1 \\
\hline Italy & 5375 & 29660 & 4 \\
\hline Japan & 100 & 1500 & 1 \\
\hline Korea & 754 & 9338 & 2 \\
\hline Mexico & 1330 & 19800 & 1 \\
\hline Netherlands & 18670 & 128220 & 25 \\
\hline Portugal & 1323 & 15000 & 1 \\
\hline Philippines & 2280 & 34470 & 1 \\
\hline Spain & 4900 & $?$ & 2 \\
\hline Switzerland & 1300 & 13200 & 3 \\
\hline Taiwan & 1963 & $>4800$ & 5 \\
\hline United Kingdom & 2480 & 23000 & 2 \\
\hline USA & 2000 & 33000 & 2 \\
\hline Venezuela & 11889 & 184800 & 3 \\
\hline Yugoslavia & 600 & $?$ & 1 \\
\hline Total & 135791 & 1370337 & 106 \\
\hline
\end{tabular}

anaerobic contact, anaerobic filter, etc.). However, because of the aggregated form of the data reported, it was not possible to determine the percentage of UASB-based plants amongst these.

By 1991, South Africa had 12 full-scale plants in operation for treating industrial effluent using AD technology (Ross, 1994). Only two of these AD systems were UASB-type reactors; one at Prospecton plant in Durban, KwaZulu-Natal Province, with a daily wastewater flow of $2600 \mathrm{~m}^{3}$, and the second at the Ceres apple processing plant in Ceres, Western Cape Province, with a daily flow of $430 \mathrm{~m}^{3}$. However, many UASB plants in South Africa and the rest of Africa are generally small or industry-specific and there is a lack of statistical data on these plants. In addition, the sensitivity of the data concerning these plants, particularly because the companies that operated them classified such information as being of a proprietary nature, has made it difficult to access statistics. Furthermore, several UASB plants in South Africa have been abandoned over the years because of high operational costs and the shortage of skilled personnel to operate them. We think that this factor - in part - accounted for the low return rate of the questionnaires sent to the industries discussed.

\section{Scenario-derived results}

To determine the growth trends for the UASB technology and, indirectly, deduce the demand for the seeding granules, the study findings are presented within a context of 4 scenarios. The first scenario seeks to examine UASB plant growth worldwide as a function of the number of plants supplied by the

\section{Table 4}

The distribution of AD technology systems from 1981 to 2004 (adopted from Van Lier, 2007)

\begin{tabular}{|l|c|c|c|c|c|}
\hline Technology & $\begin{array}{c}\mathbf{1 9 8 1 -} \\
\mathbf{2 0 0 4}\end{array}$ & $\begin{array}{c}\mathbf{1 9 8 1 -} \\
\mathbf{1 9 9 7}\end{array}$ & $\begin{array}{c}\text { \% (1981- } \\
\mathbf{1 9 9 7})\end{array}$ & $\begin{array}{c}\mathbf{1 9 9 8 -} \\
\mathbf{2 0 0 4}\end{array}$ & $\begin{array}{c}\text { \% (1998- } \\
\mathbf{2 0 0 4}\end{array}$ \\
\hline UASB & 1046 & 853 & 55 & 193 & 37 \\
\hline EGSB/IC & 362 & 87 & 19 & 275 & 53 \\
\hline AF & 152 & 147 & 8 & 5 & 1 \\
\hline CSTR & 152 & 142 & 8 & 10 & 2 \\
\hline Lagoon & 95 & 74 & 5 & 21 & 4 \\
\hline Hybrid & 57 & 47 & 3 & 10 & 2 \\
\hline FB & 38 & 33 & 2 & 5 & 1 \\
\hline Totals & 1902 & 1383 & 100 & 519 & 100 \\
\hline
\end{tabular}

most dominant market technology vendor suppliers for the AD systems, mainly Biothane Corporation, Pagues Inc., and ADI Systems Inc. The second scenario focuses on the annual growth of UASB technology in comparison to other AD systems, from its inception in the 1970s, to 2007. The data used was for the three dominant technology vendor-suppliers (Biothane, Pagues, and ADI). Although there are other market players in Asia and Africa, their market role is relatively insignificant, and they were therefore not considered in this study.

Thirdly, we present data to illustrate the growth in number and distribution of UASB plants in different continents, and, hence, to infer where future feasible markets for this technology may be more probable. Finally, data on UASB plants as a function of the industrial sectors served (e.g. breweries, chemicals, beverages, etc.), and the trends in the number of UASB plants in these industries compared with the data for the EGSB plants, are presented. The comparative data illustrates how future UASB demand may be adversely affected through aggressive introduction and uptake of the EGSB technology. Our findings on the market growth trends for AD systems in each scenario aided in predicting the future demand for seeding granules.

\section{$A D$ plant distribution globally}

Van Lier (2007) reported that about 1900 AD vendor-supplied systems were in operation worldwide by 2004 , as summarised in Table 4. The UASB plant was the dominant technology in the development and application of AD systems, and constituted $55 \%$ (based on $1902 \mathrm{AD}$ plants) of the market share between 1981 and 2004. However, these statistics were based on systems supplied by major global suppliers (e.g. Paques, Biothane, ADI, etc.), and the figures are likely to be much higher if the plants developed by local suppliers are also taken into account. Nevertheless, the data provided useful insights into the distribution of market share among different $\mathrm{AD}$ wastewater treatment technologies.

In addition, the statistics suggest that high-rate systems (UASB, anaerobic filter (AF), hybrid (H) systems, and fluidisedbed (FB) systems) had the highest market penetration and comprised $68 \%$ of all AD systems. The results of Van Lier (2007) corroborated those reported earlier by IEA Bioenergy (2001), where the high-rate systems had market dominance of $67 \%$, based on 1300 vendor-supplied AD systems. The UASB and the EGSB/IC systems notably had a combined market share of $74 \%$.

To determine the impact of market dynamics on the evolution of market share for a given technology, the period from 1981 to 2004 was divided into 2 time-lines (1981 to 1997 (pre1997), and 1998 to 2004 (post-1997) (Table 4). From 1998 to 2004, 519 vendor-supplied AD systems were installed, and 
distributed as shown in Table 4. The analysis showed that ultra-high rate systems (EGSB/IC) grew in popularity over this period, evidenced by their market share increase from $19 \%$ to 53\% pre-1997.

Concurrently, competing technologies like high-rate systems (e.g. fluidised bed (FB) and anaerobic filters (AF)) almost disappeared from the market. For instance, only 5 plants of each technology type were constructed over the 7-year period; this translates to less than 1 plant per year in each form of treatment technology system. Therefore, high-rate technologies did not consolidate their market share in the wastewater treatment industry due to factors attributed either to the technical problems experienced in several full-scale plants, making them less appealing to the clients, or to increased competition from other forms of $\mathrm{AD}$ systems that had superior performance characteristics.

During the post-1997 period, the numbers of ultra-high rate systems (e.g. EGSB/IC) increased dramatically in comparison to the UASB systems (see Table 4). For example, $275 \mathrm{EGSB} / \mathrm{IC}$ plants were constructed over the 7-year period, with an average annual installation of 39 plants. Van Lier (2007) attributed this rapid growth to the increasing operational experiences and higher availability of the indispensable seeding granules for the ultra-high rate systems. Therefore, it is reasonable to anticipate that such systems may become the most dominant AD technology with the highest market penetration in the future. Again, the UASB and EGSB/IC systems had a combined market share of $90 \%$ whilst the other treatment technologies almost disappeared from the market because of competition and the good performance of the granular systems (UASB and EGSB/IC).

A comparison of UASB market share over the two periods, i.e. pre-1997, and post-1997, showed a percentage share decrease from $55 \%$ to $37 \%$. These findings suggest a potential future decline in the UASB technology market share, primarily because of increased competition from the EGSB/IC systems. Therefore, as the global demand for UASB plants shrinks, it can be argued that the need for the seeding granules will also decline. This will result in a diminishing need for research directed at enhancing the performance of the granular sludge. Thus, these findings emphasise the importance of understanding the influence of market dynamics on the evolution of research needs in a particular field.

\section{Vendor-based AD systems market analysis}

The annual market trends for the installation and operation of AD systems from 1976, coinciding with the inception of the UASB technology, to 2007 were investigated. The data from the vendors' website (Biothane Corporation, 2008) as well as from published peer-reviewed articles (Frankin, 2001; Kassam et al., 2003) were analysed. Using the statistical data reported by Frankin (2001) and Kassam et al. (2003), the annual distribution of the AD systems for the three major suppliers are presented in Figs. 1, 2, and 3 for Paques, ADI, and Biothane, respectively.

In Fig. 1, it can be seen that the number of UASB installations by Paques Inc. increased from under 5 in 1983 to 40 plants by 1994 . This shows a 10 -fold increase in the total number of installations within a decade. However, only 5 Paques BIOPAG ${ }^{\circledR}$ Internal Circulation (IC) reactors were installed over the same period. This situation changed dramatically after 1994 when the annual number of UASB installations decreased sharply, with only 2 installations occurring in 2000. Over the same period, the IC systems experienced rapid market growth, increasing from 2 plants in 1994 to 30 installations in 2000. Notably,

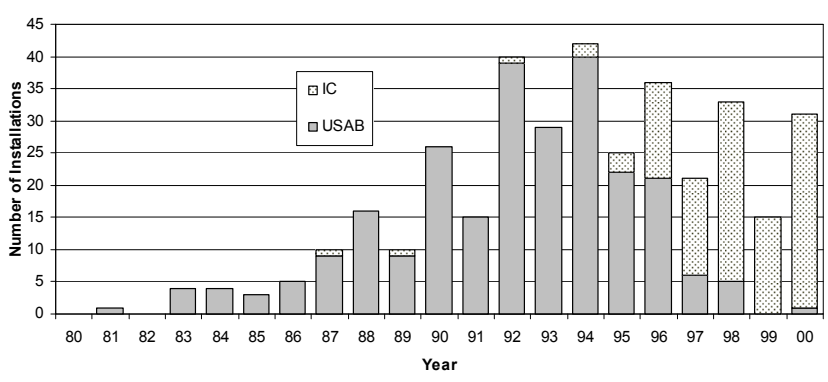

Figure 1

Anaerobic digestion installations by Paques Inc. from 1980 to 2000 (data source: Kassam, et al., 2003)

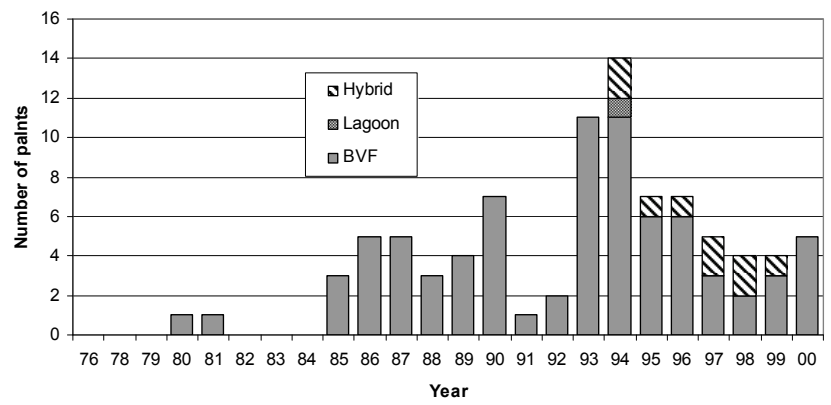

Figure 2

Anaerobic digestion installations by ADI Systems Inc. from 1980 to 2000 (data source: Kassam et al., 2003)

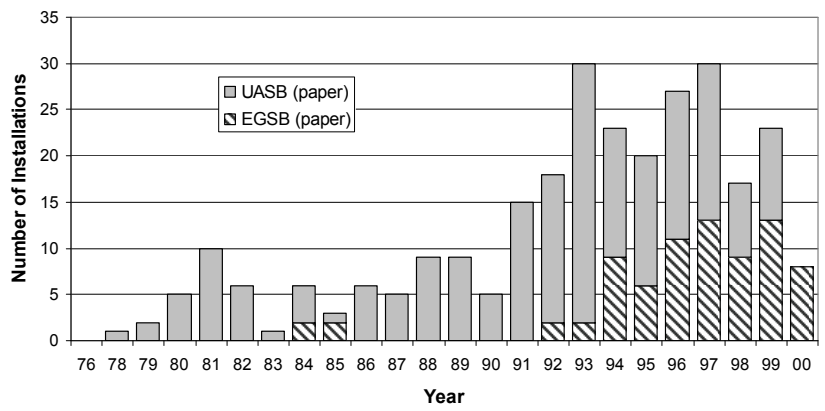

Figure 3

Anaerobic digestion installations by Biothane Corporation from 1980 to 2000 (data source: Kassam et al., 2003)

Paques Inc. had no operational UASB or IC systems before 1981; however, data shown in Fig. 1 represent a total of 366 installations (USAB: 255; IC: 111) constructed over the 20-year period, with an average of 12 UASB plants installed per year.

In Fig. 2, the market trends are presented for the anaerobic systems supplied by ADI Systems from 1979 to 2000, comprising of the ADI Bulk Volume Fermentor ${ }^{\circledR}$ (BVF), ADI Hybrid, and the lagoon technologies. Statistics show that the BVF system was the most favoured technology supplied by ADI Systems. However, the market growth for this technology remained erratic, as no steady trend could be discerned from 1980, its entry into the market, to 1992. The years 1993 and 1994 showed the highest number of plants constructed; however, thereafter the number of new plants decreased dramatically, reaching a minimum of 2 plants by 1999. Both the ADI hybrids and the lagoon treatment systems had a minor share of the market and accounted for a total of 10 installations over the entire period. Notably, the ADI systems did not install a single UASB treatment system. 
Biothane Corporation was the first company to install an UASB reactor in the late 1970s (Fig. 3). Between 1976 and 1990 market growth for the UASB installations fluctuated widely and no clear trend of growth could be inferred from these data. After 1990, the number of UASB plants installed increased to 10 or more per year, though this growth declined rapidly after 2000. Conversely, while only 7 EGSB plants had been installed by 1993 , the number increased to 13 installations by 1997 , and EGSB installations appeared to be most dominant after 1997. In addition, Biothane also supplied CSTR AD systems (Biothane Corporation, 2008), and only 6 installations were completed between 1992 and 2000; we therefore considered these numbers to be of no significance for this study.

Using the data on $\mathrm{AD}$ plant installations by Biothane Corporation (2008), the market trend analyses for the UASB and EGSB technologies were re-examined for a period of 32 years from 1976 to 2007; the results are summarised in Fig. 4. Over this period, Biothane installed 474 plants worldwide with EGSB and UASB technologies accounting for 196 and 243 installations, respectively. From Fig. 4, 211 UASB plants were installed between 1976 and 2000, and the last 9 years of the record (1992 to 2000) accounted for 64\% of the total installations. By contrast, from 2001 to 2007 there was a sharp decline in the number of UASB plants installed per year, from double figures to single figures, and by 2007 only one plant was completed. In addition, over the last 8 years of the period under investigation, the UASB technology contributed only $21 \%$ of the total plants constructed by the Biothane Corporation globally.

The EGSB experienced slow and erratic market growth prior to 2000 and only accounted for about $36 \%$ of the AD systems supplied to different industrial clients by the Biothane Corporation. After 2000, the number of EGSB installations each year in the wastewater industry stabilised and a total of 118 plants were constructed between 2001 and 2007, accounting for $79 \%$ of all plants installed by the Biothane Corporation over this period. By combining the statistical data for the AD installations built by the three major vendors, the market trends were analysed and the findings are summarised in Fig. 5. The results suggest that Paques Inc. and Biothane Corporation were the major suppliers of the AD systems worldwide, accounting for $50 \%$ and $38 \%$ of new plants, respectively, in the period between 1978 and 2000.

The data also show the market trends for the most dominant technologies, UASB and EGSB, as a function of time. Moreover, the data point to the phasing-out of high-rate systems such as the UASB due to increasing market competition caused by the highly efficient ultra-high rate systems, in this case the EGSB and IC reactors. This observation is supported by the annual number of plants installed by Paques Inc. and Biothane Corporation worldwide, with the EGSB and IC systems experiencing the greatest growth in market share since 2000. The high market growth for the ultra-high rate systems is attributed to their small footprint, high loading capacity, ability to handle effluents with a wide range of COD concentrations, and their very low hydraulic retention time (HRT). These findings suggest that it is unlikely that the demand for seeding granules in the traditional UASB reactors will increase in the foreseeable future, because the number of plants being built each year has continued to decline rapidly.

\section{Geographical distribution of $A D$ systems}

An alternative approach applied to establish the potential growth of a given technology is through examination of its

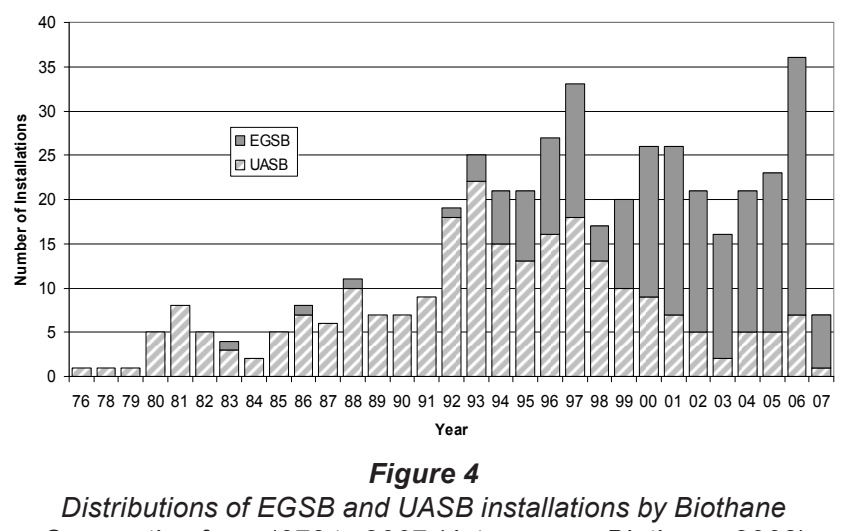

Corporation from 1976 to 2007 (data source: Biothane, 2008)

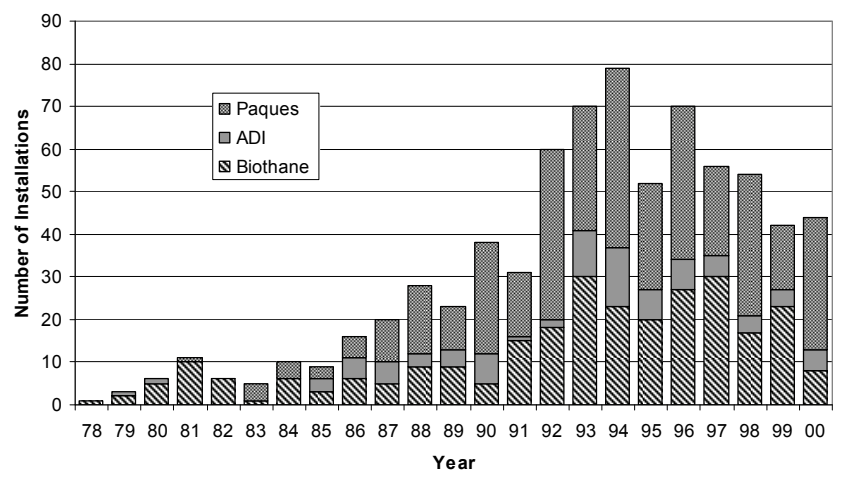

Figure 5

Global installations of $A D$ systems by Paques Inc, Biothane Corporation, and ADI Systems Inc. technology vendors from 1978 to 2000

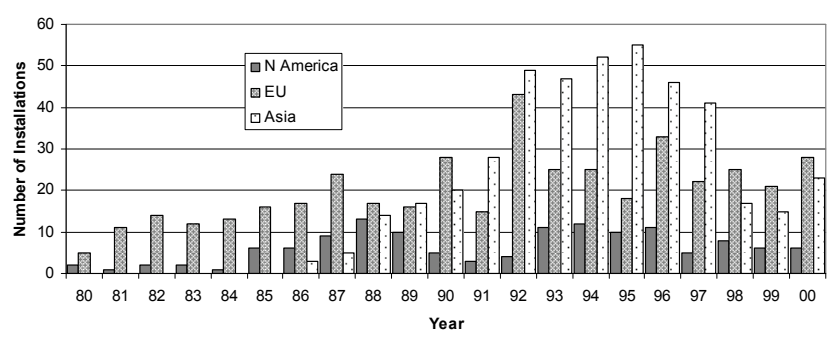

Figure 6

Annual AD system installations in North America, Asia and Europe from 1980 to 2000

growth per country or continent. This was done to determine potential regions of future market demand for the UASB technology. Frankin (2001) illustrated that most AD systems were installed in the OECD countries, where 12 countries accounted for $70 \%$ of all of the plants built between 1980 and 2000 . Figure 6 shows the number of AD systems constructed in 3 continents: North America, Asia and Europe. The findings reveal that the market for AD systems stabilised in Europe from 1996, with 20 to 30 plants installed per year up to 2000 .

The strong economic growth in Asia during the early to mid-1990s led to high market demand for AD systems. The period of high economic growth correlates with the annual installation of between 40 and 50 plants up to 1997. Thereafter, the numbers of plants installed per year declined sharply due to the Asian economic crisis of the late 1990s. Because of the low number or absence of AD systems in Africa and Australasia, these latter regions' data were not included in our analysis. Due 
to the decline of the UASB technology since 2000, it is unlikely to be the dominant technology in Africa or Australasia. The American market trend for the AD systems was found to be highly volatile and the number of installed plants was less than 10 per year. It was unclear what the underlying causes were for this trend, as the North-American continent was characterised by high diversity and density of industries that generate large quantities of effluent containing high organic loads.

Frankin's 2001 study (Frankin, 2001) showed that the UASB technology accounted for $62 \%$ of all of the plants installed up to 1997. However, the global UASB market share decreased to $56 \%$ of all the plants installed by 2000 , with a corresponding increase in the number of EGSB plants by about $50 \%$. In summary, from 1997 to 2000, the UASB and EGSB technologies constituted $84 \%$ of the total AD systems installed worldwide, compared to $76 \%$ over the period from 1990 to 1996 . Therefore, it is clear that while granular sludge systems experienced high growth rates in the 1990s, the market subsequently favoured EGSB systems (Figs. 1, 3 and 4), resulting to a gradual phasing-out of the UASB systems from the wastewater treatment industry.

\section{Industrial applications of $A D$ systems}

The distribution of the AD systems by industry is presented in Table 5. Data from Biothane Corporation (2008) showed that 474 plants were installed worldwide from 1976 to 2007, with only 4 of these being in Africa (1 in Angola and 3 in South Africa) over the same period.

Because the EGSB and USAB technologies were the most dominant AD systems, with a combined market share of about $93 \%$, their market trend growth prior to and after 2000 were further evaluated. Table 6 illustrates the distribution of the UASB and EGSB plants across 7 major industrial sectors. The food and beverage industry accounted for the highest number of installations, with a combined total of UASB and EGSB plants of 154 , with each technology contributing $67 \%$ and $33 \%$ of this total, respectively. Notably, these technologies have a near-zero application in sewage-related waste streams due to the relatively low COD concentrations of this waste. Between 1976 and 2007, 243 UASB plants were constructed, $83 \%$ before 2000 , and about $17 \%$ after 2000. Again, the results demonstrate the dramatic reduction in worldwide demand for conventional UASB plants in the wastewater treatment industry since 2000.

Conversely, EGSB market growth before 2000 was slow in the brewery, chemical, pharmaceutical, and food and beverage industries. After 2000, the technology exhibited strong growth in the pulp and paper as well as bioethanol industries. The EGSB market grew by $200 \%$ between 2000 and 2007 . Moreover, the number of EGSB plants installed (136) grew

\begin{tabular}{|l|c|c|}
\hline \multicolumn{3}{|c|}{$\begin{array}{c}\text { Table 5 } \\
\text { The distribution of AD installations by } \\
\text { Biothane Corporation (2008), as analysed } \\
\text { using data from the company website }\end{array}$} \\
\hline AD Technology & $\begin{array}{c}\text { Number of } \\
\text { plants }\end{array}$ & $\begin{array}{c}\text { Percentage of } \\
\text { total (\%) }\end{array}$ \\
\hline UASB & 243 & 51.3 \\
\hline EGSB & 196 & 41.4 \\
\hline Biopuric & 21 & 4.4 \\
\hline Lagoon & 2 & 0.4 \\
\hline CSTR & 12 & 2.5 \\
\hline Total & 474 & 100 \\
\hline
\end{tabular}

more than three times faster than the UASB technology (41 installations) post-2000. Therefore, our findings show that after 2000 the EGSB technology became the preferred technology for treating high-strength effluent in diverse industries, which is in agreement with earlier findings (Frankin, 2001; Driessen and Vereijken, 2003).

\section{Questionnaire- and interview-based results}

The Type-I questionnaire was sent to 13 industrial plants that used or were thought to use UASB technology in South Africa. Only 2 responses (out of 13) were received, representing a $15.3 \%$ response rate. In addition, only 1 plant returned the questionnaire with the correct information, whilst the second response highlighted unsuccessful earlier attempts to use UASB technology to treat effluent streams from chemical and petrochemical processes. The failure was attributed to the toxicity of the chemicals because they inhibited the growth of organic granules. The operator of the plant that provided the most useful data agreed to be interviewed to clarify and authenticate the results.

Data and information on the market trends for UASB technology application in South Africa were also solicited from 18 experts through interviews and responses to a questionnaire (Type-II questionnaire). There were 9 responses to the questionnaire $(50 \%)$, with $44.4 \%(n=4)$ of the respondents indicating they had no knowledge of the market dynamics of the UASB technology in South Africa or internationally. In addition, they claimed to have limited knowledge of the UASB technology applications, though initial contacts had rated them as experts in this field.

The expert respondents provided information by completing the questionnaire as well as granting a verbal or telephonic interview. Most of the expert respondents were either suppliers of UASB and other AD technologies to South Africa and the

\begin{tabular}{|c|c|c|c|c|c|c|c|c|c|c|}
\hline \multicolumn{11}{|c|}{$\begin{array}{l}\text { Table } 6 \\
\text { The distribution of the EGSB and UASB plants for Biothane Corporation from } 1976 \text { to } 2007 \text { by industry category } \\
\text { (Biothane Corporation, 2008) }\end{array}$} \\
\hline \multirow[t]{2}{*}{ Industry category } & \multicolumn{2}{|c|}{ UASB } & \multirow{2}{*}{$\begin{array}{l}\text { Total } \\
\text { UASB }\end{array}$} & \multicolumn{2}{|c|}{ EGSB } & \multirow{2}{*}{$\begin{array}{c}\text { Total } \\
\text { EGSB }\end{array}$} & \multirow[t]{2}{*}{ Total } & \multirow[t]{2}{*}{$\%$} & \multirow[t]{2}{*}{ UASB $\%$} & \multirow[t]{2}{*}{ EGSB \% } \\
\hline & $\leq 1999$ & $\geq 2000$ & & $\leq 1999$ & $\geq 2000$ & & & & & \\
\hline Breweries & 45 & 10 & 55 & 22 & 19 & 41 & 96 & 21.9 & 57.3 & 42.7 \\
\hline Pulp and paper & 19 & 0 & 19 & 2 & 21 & 23 & 42 & 9.6 & 45.2 & 54.8 \\
\hline Bioethanol & 9 & 3 & 12 & 0 & 17 & 17 & 29 & 6.6 & 41.4 & 58.6 \\
\hline Chemical \& pharmaceuticals & 30 & 5 & 35 & 18 & 33 & 51 & 86 & 19.6 & 40.7 & 59.3 \\
\hline Fermentation & 15 & 2 & 17 & 6 & 7 & 13 & 30 & 6.8 & 56.7 & 43.3 \\
\hline Food and beverages & 84 & 19 & 103 & 12 & 39 & 51 & 154 & 35.1 & 66.9 & 33.1 \\
\hline Sewage & 0 & 2 & 2 & 0 & 0 & 0 & 2 & 0.5 & 100 & 0.0 \\
\hline Total & 203 & 41 & 243 & 60 & 136 & 196 & 439 & 100 & & \\
\hline
\end{tabular}


rest of the African continent, or representatives of major global UASB technology suppliers, such as Biothane Corporation and Pagues Inc. The experts' information mapped the underlying market dynamics of the UASB technology applications in South Africa and globally, though most of the data were expressed qualitatively. The survey findings concerning the challenges facing the growth of the UASB technology in South Africa and Africa were also solicited from the experts.

Most experts indicated that the demand for the UASB seeding granules in South Africa and worldwide was low or non-existent, and that a commercial industrial plant for producing high-quality seeding granules was therefore not economically feasible. For example, only 2 of the 9 experts that responded expressed an opinion indicating that there could be a real demand for seeding granules in the wastewater treatment industry in South Africa. Their views can be explained in the context of the current monopoly enjoyed by a single supplier for the granules inSouth Africa. However, several experts indicated that 20-30 t of sludge are generated daily in South Africa, accompanied by excessive production of granules.

Through interviews with experts working in companies that supply UASB technology in South Africa, we established that the permeation of the UASB technology into other African countries was also very low; less than 10 plants had been built outside South Africa. The other African countries that operate UASB plants are: Angola, Ghana, Tanzania, Nigeria, Kenya, Uganda and Mauritius, with most plants in the alcohol, food and beverage fermentation-related industries. Therefore, the data suggest that there is very low demand for UASB technology in African countries, which directly indicates a very low, or no demand for the seeding granular sludge.

According to estimates by Driessen and Vereijken (2003), anaerobic granular sludge production is approximated to be 0.02 $\mathrm{kgTS} / \mathrm{h} \ell$ and, therefore, large quantities of granules are generated annually. Because seeding granules are only required by new plants and with South Africa having a very small market demand for treating high COD waste (only about 1 to 2 smallscale plants are installed annually), most of the sludge is currently used as compost, or stored in tanks before disposal. The excess quantities of seeding granules were deemed sufficient to meet all of the needs of new UASB installations. Currently, according to the experts' estimates, South Africa has approximately 20 UASB plants (mostly small-scale), and their combined demand was insufficient to justify the construction of a plant for producing seeding granules.

In addition, the experts indicated that market demand for granules for use in UASB plants in Europe and Asia was currently fully met. Although there may be demand for the granules in Eastern Europe, where increasing numbers of UASB plants are now under construction, the demand for granules can easily be met from the neighbouring Western European countries. The interviews and questionnaire responses revealed that the UASB technology is faced with several challenges that hamper its widespread application for treating high-strength effluent in South Africa. Relatively low demand for the UASB technology could be attributed to poor enforcement of environmental law, absence of incentives for companies to treat high-strength organic waste streams, and the high installation costs of UASB plants.

For example, South African candidate industries who could be potential users of UASB technology such as the food and beverage, pharmaceutical, fruit and confectionary industries have not yet adopted this technology, citing high investment capital as the major hindrance to constructing new plants. The challenge lies in promoting the acceptance and implementation of UASB technology in South Africa, for example, by offering locally-designed plants for which initial investment cost is reasonably low. This type of approach has proven to be successful in Mexico, where $76 \%$ of the anaerobic market, including UASBs, is designed, constructed, and operated by national companies (Monroy et al., 2000).

Secondly, the high cost per unit volume of using the UASB technology for effluent treatment makes it highly unattractive. The attractiveness of UASB technology could be increased if applications of UASB technology in addition to the traditional application for effluent treatment were designed, e.g., producing a source of renewable energy, for instance, through biogas production or for co-generation of electricity. This would have the additional merit of reducing the volume of greenhouse gases released into the atmosphere. Notably, according to expert estimates, the cost of the seeding granules for a UASB plant only accounts for about $0.5 \%$ to $1 \%$ of the total plant cost, and in many cases the seeding sludge is offered to clients at no additional cost as part of the commercial agreements.

In addition, it is important that the final treated effluent should be of a standard that would allow it to be re-used. This is a highly attractive option given that South Africa is a waterstressed country, and the growing demand for water provides a strong driver to encourage recycling of treated water. Moreover, owing to the effectiveness of UASB technology in removing high concentrations of organic material (e.g. COD), it would make sense to offer companies economic benefits in terms of savings or a considerable reduction in their effluent discharge tariffs.

Thirdly, the high transportation and storage costs of sludge, when transported from source to the new UASB plants, were viewed as a challenge. The challenge can be addressed through the development of specialised equipment for transporting seeding granules, particularly when the sludge is highly concentrated. However, this option is likely to increase the cost of the granules. The second option is to increase the activity of the sludge through the dewatering process. Normally the sludge that is obtained from the plants is of very low concentration and large quantities are required for start-up of new plants. Also, there is a need to improve the way the in which the sludge is made available to new customers.

Finally, within the South Africa wastewater treatment industry context, 2 technologies have increasingly become more dominant in place of the UASB technology, namely, aerobic filters (AF) and membrane bed reactors (MBR). The AF systems are preferred in diverse industries due to the short sludge retention times and their ability to treat effluent containing toxic fatty acids. Moreover, the MBR technology is edging out the UASB technology in South Africa because, unlike UASB, it does not require sludge separation. Also, no seeding granules are required and the treatment process commences instantly, as opposed to the long start-up periods required in an UASB plant. Finally, the MBR system is highly compact with few moving parts, making it easier to operate and maintain. Therefore, in the context of South African wastewater industry, MBR and AF technologies have become the preferred treatment options over the past few years. Again, this points to the strong likelihood that the demand for seeding granules is likely to be low.

\section{UASB technology: the political and market context}

At the time when this research was carried out (2007) there was a worldwide energy crisis. In the South African context, the 
energy crisis peaked in May 2007 because of limited power supplies from the national power utility. Elsewhere in the world, oil prices had risen by more than $500 \%$ by February 2008 . Even under these conditions, the UASB technology showed no signs of recovery or increased demand, such as happened in the 1970s when the oil price rose by almost $200 \%$ per barrel.

Although both political and economic drivers were similar to those in the 1970s, this did not provide sufficient impetus to increase market demand for UASB plants. For example, the energy crisis increased demand for biogas in countries such as The Netherlands (Raven and Verbong, 2004) and USA (Kassam et al., 2003). The current energy crisis in South Africa could offer positive spin-offs in terms of providing an enabling environment essential for addressing the challenges to adopting UASB technology discussed above. Furthermore, wide application of UASB technology has the distinct merit of being able to reduce the pollution loads entering water courses in South Africa.

Legislative instruments provide another means of creating the economic motivation for the wider application of the UASB technology. This could be achieved through creation of tax incentives, which would promote the use of UASB technology and other anaerobic treatment technologies, because of their dual functionality of effluent treatment and energy recovery. Such mechanisms may lead to an increase in the demand for seeding granules and provide a justification for granule production at full plant-scale.

Therefore, we argue that the absence of national policy and suitable legislative frameworks (political context) for the use of anaerobic technologies appears to limit the extent to which these technologies can be applied to treat waste streams with high organic loads. This may partly account for countries like South Africa, Canada and USA having low penetration of the UASB technology in comparison to countries such as Mexico, Sweden, The Netherlands and India. For example, by 2000, Mexico had installed 3 times more digesters than Canada and over $90 \%$ of the number of digesters operating in the USA (Monroy et al., 2000). In the context of technology development, both political and market factors appear to have a critical role to play in the survival of a technology in the market, as demonstrated for the UASB.

\section{Concluding remarks}

Our study has presented a market trend analysis for UASB seeding granule demand, both nationally and internationally. However, it was not possible to assess the direct market demand for UASB seeding granules because no such data had been published in the scientific literature. Instead, we addressed the challenge from a perspective of growth in the number of UASB plants in South Africa and internationally, from the time of market entry of the UASB technology in the 1970s. The proposed direct relationship between demand for seeding granules and UASB plant growth was based on the premise that seeding inoculum was necessary for each plant to start functioning.

Our findings suggest that UASB technology has been widely applied in treating high-strength effluent in a variety of industries in both developed and developing countries, but with greater intensity in developed countries up to around 2000 . The comparative studies illustrated that, worldwide, the UASB technology has increasingly been edged out of the market since 2000 because of the introduction of the EGSB system and other technologies. This points to a technology 'phase-out' and 'phase-in' phenomenon, which suggests that it is unlikely that there will be high growth in future for the UASB technology in the wastewater sector. In view of these findings, the demand for the seeding granules is also expected to be very low or non-existent, because current stocks of granules are adequate to meet the needs of the start-up processes of new UASB plants.

It is clear that those factors which may have prompted a specific research need have changed dramatically over a relatively short period of time. For example, based on the case study of the UASB technology presented in this paper, the demand for a given technology appears to be driven by market dynamics, political context, and technology push factors (efficiency and appropriateness). However, the empirical findings of this study also show that market demand is one of the most important drivers for the survival of any given technology, as demonstrated by UASB market evolution statistics, from inception of the technology in the 1970s to 2007. Research to understand granule formation and engineer seeding granules was relevant in the late 1990s and early 2000s, but market forces have since introduced new trends in research needs. This study has indicated the need for periodic review of market dynamics and its potential impact on the evolution of a given technology and its associated research needs.

The authors acknowledge that the international statistics on the distribution of UASB technology may be incomplete and the methods that we used to solicit the required data could have introduced uncertainties. However, the data obtained during this study was considered to be sufficient to enable us to predict that there will be very low future demand for UASB seeding granules - both in South Africa and internationally.

\section{Acknowledgements}

The authors acknowledge funding from the Water Research Commission under WRC Project No. KV224/09, and inputs from experts in the wastewater treatment sector in South Africa, who provided us with the basic data for this study. We also thank Dr Peter Ashton for editing the manuscript. In addition, we thank the anonymous reviewers for their comments which helped to improve an earlier version of this manuscript. This research was conducted at Stellenbosch University and the results are reported in detail in a Water Research Commission report, (WRC) Report No. KV 224/09 (Musee and Lorenzen, 2009).

\section{References}

AIYUK S, FORREZ I, DE LIEVEN K, VAN HAANDEL A and VERSTRAETE W (2006) Anaerobic and complementary treatment of domestic sewage in regions with hot climates - a review. Bioresource Technol. 97 2225-2241.

ALLEN DG and LIU HW (1998) Pulp mill effluent remediation. In: Meyers AD (ed.) Encyclopedia of Environmental Analysis and Remediation. Wiley and Sons Inc., New York. 3871-3887.

ALVES M, CAVALEIRO AJ, FERREIRA EC, AMARAL AL, MOTA M, DA MOTTA M, VIVIER H and PONS MN (2004) Characterization by image analysis of anaerobic sludge under shock conditions. Water Sci. Technol. 41 207-221.

ANONYMOUS (1988) Biogas technology in Netherlands, anaerobic waste and wastewater treatment with energy production. Netherlands Agency for Energy and the Environment, Utrecht, The Netherlands.

BIOTHANE CORPORATION (2008) Anaerobic systems. URL: http://www.biothane.com/lang EN/references.php (Accessed 6 March 2008).

BRITZ TJ, SCHALKWYK C and ROOS P (2002) Development of a method to enhance granulation at laboratory batch system. Water SA 28 49-54. 
BRITZ TJ, TRNOVEC W, VAN SCHALKWYK C and ROOS P (1999) Enhanced granulation in upflow anaerobic sludge-bed (UASB) digesters by process induction and microbial simulation. WRC Report No. 667/1/99. Water Research Commission, Pretoria.

DE MES TDZ, STAMS AJM, REITH JH and ZEEMAN G (2003) Methane production by anaerobic digestion of wastewater and solid wastes. In: Reith JH, Wijffels RH and Barten H (eds.) Bio-Methane and Bio-Hydrogen Status and Perspectives of Biological Methane and Hydrogen Production. Dutch Biological Hydrogen Foundation, Petten. 58-102.

DRIESSEN W and VEREIJKEN T (2003) Recent developments in biological treatment of brewery effluent. In: Proceedings of the $9^{\text {th }}$ Brewing Convention, Institute and Guild of Brewers, Africa Section, 2-7 March 2003, Victoria Falls, Zambia. 165-171.

ELMITWALLI TA (2000) Anaerobic treatment of domestic sewage at low temperature. PhD thesis, Wageningen University, Wageningen.

ELS ER, LORENZEN L, VAN ZYL PJ and BRITZ TJ (2005) Preliminary design guidelines for the development of a granulating reactor. WRC Report No. 1239/1/05. Water Research Commission, Pretoria.

ENVIROASIA LTD (2001) Worldwide experience: Anaerobic wastewater treatment. URL: http://www.enviroasia.org (Accessed 8 March 2008).

FANG HHP, CHUI HK and LI YY (1994) Microbial structure and activity of UASB granules treating different wastewaters. In: Seventh International Symposium on Anaerobic Digestion, 23-27 January 1994, Goodwood, Cape Town, South Africa. 80-89.

FORESTI E (2001) Anaerobic treatment of domestic sewage: established technologies and perspectives. In: Proceedings of the $9^{\text {th }}$ World Congress on Anaerobic Digestion - Anaerobic Conversion for Sustainability, 2-6 September 2001, Antwerp. 36-42.

FRANKIN RJ (2001) Full-scale experience with anaerobic of industria wastewater. Water Sci. Technol. 44 1-6.

GAVRILESCU A (2002) Engineering concerns and new developments in anaerobic wastewater treatment. Clean Technol. Environ. Polic. 3 346-362.

GROTENHUIS JTC (1992) Structure and stability of methanogenic granular sludge. $\mathrm{PhD}$ Thesis, Wageningen University, Wageningen, The Netherlands.

HABETS L (1999) The application of anaerobic wastewater and process waste treatment in the paper industry. Paper 180. In: $6^{\text {th }} I A W Q$ Symposium on Forestry Wastewaters, 6-10 June 1999, Tampere, Finland.

HARADA LHA, MOMOMOI K, YAMAZAKI S and TAKIAWA S (1994). Application of anaerobic - UF membrane reactor for treatment of a wastewater containing high-strength particulate organics. Water Sci. Technol. 30 307-319.

HULSHOFF L, EULER H, EITNER A and WUCKE A (1997) GTZ sectoral project: Promotion of anaerobic technology for the treatment of municipal and industrial sewage and wastes. In: Anaerobic Conversions for Environmental Protection, Sanitation and Re-use of Residuals. REUR Technology Series 51. FAO, Rome. 96-107.

IEA BIOENERGY (2001) Biogas and more! Systems and markets overview of anaerobic digestion. AEA Technology Environment, Culham, Abingdon, Oxfordshire, UK

JÖRDENING H.-J and BUCHLONZ K (1999) Fixed film stationary bed and fluidized bed reactors. In: Relm H-J and Reed G (eds.) Biotechnology, Vol. 11a. Wiley-VCH, Weinheim. 373-415.

KASSAM ZA, YERUSHALMI L and GUIOT SR (2003) A market study on the anaerobic wastewater treatment systems. Water Air Soil Pollut. 143 179-192.

LETTINGA G (1995) Anaerobic digestion and wastewater treatment systems. Antonie van Leeuwenhoek 67 3-28.

LETTINGA G and HULSHOFF POL LW (1991) UASB-process design for various types of wastewaters. Water Sci. Technol. 24 87-107.

LETTINGA G, HULSHOFF-POL LW and ZEEMAN G (1998) Lecture notes: Biological Wastewater Treatment, Part I Anaerobic Wastewater Treatment. Wageningen University and Research: Wageningen, The Netherlands.
LETTINGA G, VAN VELSEN AF, HOBMA SW, ZEEUW W and KLAPWY A (1980) Use of the up flow sludge blanket (UASB) reactor concept for biological wastewater treatment especially for anaerobic treatment. Biotechnol. Bioeng. 22 699-734.

LETTINGA G, VAN VELSEN AF, ZEEUW W and HOBMA SW (1979) The application of anaerobic digestion to industrial pollution treatment. In: Staffords DA, Whealthy BI and Hughes DE (eds.) Anaerobic Digestion. Applied Science Publishers, London. 167-186.

LIM HC and LEE K-S (1991) Control of bioreactor systems. In: Schüger K (ed.) Biotechnology Vol. 4. Wiley-VCH, Weinheim. 509-560.

LIU Y, XU HL and YANG SF (2003) Mechanisms and models of for anaerobic granulation in up-flow anaerobic sludge blanket reactor. Water Res. 37 661-673.

McCARTY PL (1981) One hundred years of anaerobic treatment. In: Hughes DE, Stafford DA and Wheatley BI (eds.) Anaerobic Digestion. Elsevier, Amsterdam. 3-22.

McNEILL JR (2000) Something New under the Sun: An Environmental History of the Twentieth-Century World. W.W. Norton \& Company Ltd., London.

MONROY O, FAMÁ G, MERAZ M, MONTOYA L and MACARIE $\mathrm{H}$ (2000) Anaerobic digestion for wastewater treatment in Mexico: State of the technology. Water Res. 30 1803-1816.

MUSEE N and LORENZEN L (2009) Market analysis for UASB seeding granules: local and international markets. WRC Report No. KV 224/09. Water Research Commission, Pretoria.

NEDERHORST VS, VAN STARKENBURG W and VISSCHER K (1986) Toepassing anaerobe afvalwaterzuivering: Een inventaristatie van de stand van zaken iIn Dutch). The Hague, The Netherlands.

PAUSS A and NYNS EJ (1990) Biogas plants in Europe. An updated databank. Final report, Commission of the European Communities. Catholic University of Louvain, Louvain-la-Neuve, Belgium.

PAQUES ADI (2001) Anaerobic and aerobic wastewater treatment technologies. URL: http://www.paquesadi.com (Accessed 8 March 2008).

PEREBOOM JHF and VEREIJKEN TLFM (1994) Methanogenic granule development in full scale internal circulation reactors. Water Sci. Technol. 30 9-21.

RAVEN R and VERBONG G (2004) Dung, sludge, and landfill: Biogas technology in the Netherlands, 1970-2000. Technol. Cult. 7 519-539.

ROSS WR (1989) Anaerobic treatment of industrial effluents in South Africa. Water SA 15 231-246.

ROSS WR (1994) Anaerobic digestion of industrial effluents with emphasis on solids-liquids separation and biomass retention. $\mathrm{PhD}$ thesis, University of the Orange Free State, Bloemfontein, South Africa.

SEGHEZZO L, ZEENMAN G, VAN LIER JB, HAMELERS M and LETTINGA G (1998) A review: The anaerobic treatment of wastewater of sewage in UASB and EGSB reactors. Bioresource Technol. 65 175-190.

SPEECE RE (1983) Anaerobic technology for industrial wastewater treatment. Environ. Sci. Technol. 17 9-15.

TCHOBANOGLOUS G and BURTON FL (1991) Wastewater Engineering: Treatment, Disposal and Reuse ( ${ }^{\text {rd }}$ edn.). McGraw-Hill, New York.

VAN LIER JB (2007) Anaerobic industrial wastewater treatment: Perspectives for closing waster and resource cycles. In: Proceedings of ACHEMA 2006, 28th Int. Exhibition Conference on Chemical Technology, Environmental Protection and Biotechnology, 15-19 May 2006, Frankfurt, Germany.

VESPRILLE AI, FRANKIN RJ and ZOUTBERG GR (1994) Biobed, a successful cross-breed between UASB and fluidized-bed. In: Seventh International Symposium of Anaerobic Digestion. 23-27 January 1994, Goodwood, Cape Town, South Africa. 587-590.

VERSTRAETE W, DE BEER D, PENA M, LETTINGA G and LENS P (1996) Anaerobic bioprocessing of organic wastes. World J. Microbiol. Biotechnol. 12221 - 238.

ZOUTBERG GR and DE BEEN P (1997) The Biobed EGSB (Expanded Granular Sludge Blanket) system covers short comings of the UASB reactor in the chemical industry. Water Sci. Technol. 35 183-188. 